\title{
Why it is Disrespectful to Violate Rights: Contractualism and the Kind-Desire Theory
}

\author{
Janis David Schaab ${ }^{1,2}$
}

Published online: 7 January 2017

(C) The Author(s) 2017. This article is published with open access at Springerlink.com

\begin{abstract}
The most prominent theories of rights, the Will Theory and the Interest Theory, notoriously fail to accommodate all and only rights-attributions that make sense to ordinary speakers. The Kind-Desire Theory, Leif Wenar's recent contribution to the field, appears to fare better in this respect than any of its predecessors. The theory states that we attribute a right to an individual if she has a kind-based desire that a certain enforceable duty be fulfilled. A kind-based desire is a reason to want something which one has simply in virtue of being a member of a certain kind. Rowan Cruft objects that this theory creates a puzzle about the relation between rights and respect. In particular, if rights are not grounded in aspects of the particular individuals whose rights they are (e.g., their well-being), how can we sustain the intuitive notion that to violate a right is to disrespect the right-holder? I present a contractualist account of respect which reconciles the Kind-Desire Theory with the intuition that rights-violations are disrespectful. On this account, respect for a person is a matter of acknowledging her legitimate authority to make demands on the will and conduct of others. And I argue that kind-based desires authorize a person to make demands even if they do not correspond to that person's well-being or other non-relational features.
\end{abstract}

Keywords Contractualism · Rights · Kind-Desire Theory · Respect · Dignity · Second-person standpoint

Janis David Schaab

jds20@st-andrews.ac.uk

1 Department of Philosophy, University of St Andrews, Edgecliffe, The Scores, St Andrews, Fife KY16 9AL, UK

2 Department of Philosophy, University of Stirling, Pathfoot Building, Stirling, Stirlingshire, FK9 4LA, UK 


\section{Introduction}

Leif Wenar's analysis of rights purports to do a better job at accommodating our ordinary understanding of rights than its competitors (2013b). His Kind-Desire Theory states that we attribute a right to an individual if she has a kind-based desire that a certain enforceable duty be fulfilled. A kind-based desire is a reason to want something which one has simply in virtue of being a member of a certain kind - and thus independently of one's psychological states or well-being. Rowan Cruft, however, objects that the Kind-Desire Theory creates a puzzle about the relation between rights and respect (2013). In particular, if rights are not grounded in aspects of the particular individuals whose rights they are, how can we sustain the intuitive notion that to violate a right is to disrespect the right-holder?

In this paper, I invoke a contractualist account of respect to reconcile the KindDesire Theory with the intuition that violating rights is disrespectful. I will begin by sketching Wenar's theory of rights and highlighting the ways in which it purports to be superior to its competitors (Sect. 2). Subsequently, I will introduce Cruft's objection that the Kind-Desire Theory is challenged by our intuitions about the link between rights and respect (Sect. 3). I will attempt to reconcile Wenar's analysis of rights with our intuitions concerning respect. In particular, I will propose a contractualist account of respect that drives a conceptual wedge between the notions of respecting a person on the one hand, and responding to aspects of her psychology or well-being on the other. Finally, I will attempt to reply to potential objections to the account presented here (Sect. 4). I will conclude that the Kind-Desire Theory of rights and the contractualist account of respect form a fruitful synthesis that explains both the way rights-attributtions are ordinarily understood and our intuitions concerning the link between rights and respect (Sect. 5).

\section{The Kind-Desire Theory of rights}

In his seminal work on legal concepts, Wesley Hohfeld provides an analysis of the logical structure of rights which serves as the starting point for most contemporary theorizing about rights (Hohfeld 1964; cf. Wenar 2015). Hohfeld observes that 'right', both in ordinary usage and in legal disputes, is used to refer to several distinct logical relations that can hold between legal parties. Yet, he singles out one of the referents of rights-talk, the so-called claim-right, as paradigmatic-and to this day a significant number of theorists side with him on this issue (e.g., Kramer and Steiner 2007; Streenivasan 2005; Wenar 2013b). What makes a claim-right so special is that it is correlated with a directed duty (Hohfeld 1964: 33). More specifically, $\mathrm{X}$ has a claim-right that $\mathrm{Y}$ do $\varphi$ if and only if $\mathrm{Y}$ has a duty to $\mathrm{X}$ to do $\varphi$, where the clause 'duty to $\mathrm{X}$ ' indicates that $\mathrm{Y}$ wrongs $\mathrm{X}$ (i.e., $\mathrm{Y}$ does not merely commit a wrong) if she does not do $\varphi .{ }^{1}$ In short, Y's duty to $\varphi$ is owed to $\mathrm{X}$.

\footnotetext{
1 Actually, siding with Cruft and Darwall, I believe that there are directed duties that are not correlated with rights (Cruft 2013: 204 and 209; Darwall 2013a: 28, note 10). For example, it seems that we sometimes owe a duty to be grateful to others. Yet, we do not ordinarily say that these others have a right
} 
Hohfeld has thus already provided a widely-accepted logical analysis of the most important-and presumably philosophically most interesting-form that rights can take. What the rights-theorist is now left with, according to Wenar, is the task of singling out the conditions under which such claim-rights ${ }^{2}$ are attributed by competent speakers. ${ }^{3}$ Thus, Wenar's aim is to come up with a theory that accommodates "all and only rights-assertions that make sense to competent users of the language" (2013b: 203). Note that this is not the aim of capturing all and only correct rights-attributions. Wenar's objective is not to develop a theory of which rights there are or should be but to provide an account of how rights-attributions are ordinarily understood (2013b: 209-210). And he argues that the two most prominent theories of rights - the Will Theory and the Interest Theory-notoriously fail to provide such an account (2013b: 203-206).

The Will Theory, most prominently developed by H. L. A. Hart, states that X has a right that $\mathrm{Y}$ do $\varphi$ if and only if $\mathrm{X}$ can legitimately waive or enforce $\mathrm{Y}$ 's duty to do $\varphi$ (Hart 1955). ${ }^{4}$ It thus ties the notion of rights to the notion of freedom: a right gives its holder sovereignty over a certain domain in which her will is to govern normative relations. Wenar points out two widely recognized problems with the Will Theory (2013b: 203). First, the Will Theory cannot account for rightsattributions to non-human animals and other beings who are not capable of sovereignty, e.g., children or the comatose (cf. Hart 1955: 181; MacCormick 1984). After all, these beings do not seem to be capable of the kinds of choices which the Will Theory takes to warrant the attribution of rights. Second, the Will Theory notoriously denies the existence of unwaivable or inalienable rights, i.e., rights that we possess even though we do not have the authority to waive the respective duties (cf. Hart 1955: 176; MacCormick 1977). Rights which are ordinarily taken to be unwaivable or inalienable include the right not to be enslaved and the rights of citizens under criminal law.

The Interest Theory, whose most prominent defender is Joseph Raz, states that " ' $\mathrm{x}$ has a right' if and only if $\mathrm{x}$ can have rights, and other things being equal, an aspect of x's well-being (his interest) is a sufficient reason for holding some other person(s) to be under a duty" (Raz 1984: 195). On the most plausible reading of Raz's theory, X's interest's being "a sufficient reason" for taking Y to be dutybound means that X's interest is what grounds or justifies Y's duty (Cruft 2013:

\footnotetext{
Footnote 1 continued

to our gratitude. The reason seems to be that it would be inappropriate to enforce the respective duties. Wenar, too, is sympathetic to this view (2013b: 214, note 24). For the purposes of this essay, however, I will follow large parts of the literature by simply assuming that every directed duty corresponds to a claim-right.

2 Since this article is concerned with claim-rights only, I will henceforth simply refer to them as 'rights'.

3 Note that some rights-theorists do not identify capturing the ordinary understanding of rights as their primary task (e.g., Hart 1982: 193; Kramer and Steiner 2007: 294-299). For objections to their alternative methodologies, see Wenar (2008).

${ }^{4}$ For another prominent version of the Will Theory, see Steiner (1994).
} 
205). ${ }^{5}$ The main problem with the Interest Theory, according to Wenar, is that it cannot accommodate cases of rights that serve, not their holder's, but one or more third parties' interests (2013b: 204). For example, as Raz concedes, the right of journalists to protect their sources is not based on their interests. If this right is based on an interest at all, it is more likely to be the public's interest in being informed (1984: 206). Or consider the right of a promisee to have promises made to her fulfilled. Wenar points out that this right does not seem to hinge upon the promisee's having an interest in the fulfilment of the promise at all (2013b: 204). To the contrary, no matter how conducive the fulfilment of a given promise is to a promisee's well-being, the promisor owes fulfilment of the promise to the promisee.

\subsection{Kind-based desires and rights}

In light of this mismatch between a person's interests and her rights, Raz suggests that rights might be "vested in right-holders because they possess certain general characteristics: they are the beneficiaries of a promise, nationals of a certain state, etc." (1984: 208). Wenar takes this suggestion as his starting point for developing a new theory of rights, ${ }^{6}$ the Kind-Desire Theory:

Consider a system of norms $S$ that refers to entities under descriptions that are kinds, $D$ and $R$. If and only if, in circumstances $C$, a norm of $S$ supports statements of the form:

1. Some $D$ (qua $D$ ) has a duty to $p h i$ some $R$ (qua $R$ ); where "phi" is a verb phrase specifying an action, such as "pay benefits to", "refrain from touching", "shoot", and so on.

2. $\quad R$ s (qua $R \mathrm{~s}$ ) want such duties to be fulfilled; and

3. Enforcement of this duty is appropriate, ceteris paribus;

Then: the $R$ has a claim-right in $S$ that the $D$ fulfil this duty in circumstances

C. (Wenar 2013b: 219)

Note that condition 1 requires, not only that the $D$ (qua $D$ ) has a duty to perform a certain action, phi, but also that she has a duty to perform this action under the particular description ' $p h i$ some $R$ (qua $R$ )'. Thus, for example, Wenar's theory correctly predicts that prison wardens do not have a legal right that prisoners stay in prison (Wenar 2013a, b: 211). For, even though prisoners have a legal duty to stay in prison, the legal system that attributes this duty to them does not mention wardens

\footnotetext{
5 Note that Matthew Kramer's version of the Interest Theory holds that $\mathrm{X}$ has a right that $\mathrm{Y}$ do $\varphi$ if the fulfillment of Y's duty to $\varphi$ "necessarily involves the protection of some aspect of [X's] situation that is generally beneficial for any typical human being or collectivity or non-human creature" (Kramer and Steiner 2007: 290). This view seems to avoid the difficulty for Raz's account which I mentioned since it is not committed to the notion that the right-holder's interests ground the right. However, as Streenivasan points out, Kramer's view faces a different, yet equally troublesome objection (Streenivasan 2005: 262-264, 2010: 485-486; for Kramer's reply and a criticism thereof see Kramer and Steiner 2007: 301-304; Wenar 2008: 258, note 9, respectively).

${ }^{6}$ For previous attempts to develop a preferable alternative to the Will and Interest Theories, see Streenivasan $(2005,2010)$ and Wenar (2005). For objections to these, see Kramer and Steiner (2007).
} 
in the explication of that duty. That is, it does not specify that 'prisoners (qua prisoners) have a duty to stay in the prisons of wardens (qua wardens)'.

For our purposes, however, condition 2 is the more interesting one. It requires that the $R$ has a kind-based desire, i.e., a desire qua $R$, that $D$ phi the $R$. It is important to note that this condition does not refer to the $R$ 's psychological states. Rather, the condition requires that every $R$, in virtue of being a member of the kind $R$, has a reason to want the duty in question to be fulfilled (Wenar 2013b: 207). Wenar defines a kind as "a set of entities that share defining characteristics" (2013b: 218) He goes on to list three classes of kinds that might warrant the attribution of kind-based desires.

The first class of kinds that Wenar mentions are social roles that entail special duties; that is, bearers of these roles have certain duties solely in virtue of bearing these roles (2013b: 206-207). The kind-based desire attributed to bearers of such roles is simply the desire to fulfil these duties. For example, Wenar observes that, historically, the right to free speech used to be linked to the desire of citizens (qua citizens) to speak freely which in turn was based on their duty (qua citizens) to participate in public discourse (2013b: 221). Indeed, Wenar suggests that, originally, all rights were attributed on the basis of such duty-laden roles.

Nowadays, however, a role need not entail any duties to warrant the attribution of a kind-based desire. The role of a promisee, for example, does not seem to come with special duties. At any rate, no such duty seems to serve the purpose of motivating the attribution of rights to promisees. Hence, the second class of kinds that Wenar mentions are roles which warrant the attribution of kind-based desires, not because they assign duties to the ones who bear the roles, but by virtue of rolenorms (2013b: 216). That is, the desires associated with these roles are entailed in the significance that these roles have within the system of norms of which they form parts. Accordingly, to understand these roles is to know that certain desires are attributed to their bearers. In the case of promisees, the norm governing the role attributes to all promisees (qua promisees) a desire that promises that were made to them be fulfilled. According to Wenar, desire-ascriptions based on role-norms form an essential part of our social lives: they help us make sense of social situations and we rely on them in navigating social reality (2013b: 215).

The third class of kinds that warrant the attribution of kind-based desires is the class of natural kinds such as human beings, children, and animals. Wenar suggests that, for the case of a natural kind, the kind-based desires consist in the interests that members of this kind have qua their membership in this kind (2013b: 227). Wenar observes that, here, his theory partly coincides with versions of the Interest Theory which embrace an "objective list" account of well-being that take the quality of a creature's life to depend not only on her balance of pleasure over pain, but also on the extent to which it contains intrinsic goods such as knowledge and meaningful relationships (2013b: 226-227).

The Kind-Desire Theory appears to escape the problems faced by the Interest Theory and the Will Theory. In particular, since it does not rely on rights' furthering the well-being of their holders in all cases, it can account for rights which do not reflect the interests of their holders-as opposed to the Interest Theory. For example, it can account for the right of journalists to conceal their sources by 
referring to a norm according to which journalists-qua journalists, and thus independently of their individual interests-have a desire to keep their sources secret. Moreover, since the Kind-Desire Theory has the conceptual resources to attribute rights solely on grounds of facts about a right-holder's well-being which hold by virtue of her membership in a natural kind, Wenar's theory can accommodate the rights of creatures with a limited capacity for choice, as well as unwaivable rights - as opposed to the Will Theory. After all, while some kinds (e.g., the role of journalist) can be entered and exited by an act of will, membership in other kinds (such as more robust social roles, and natural kinds) is not sensitive to the will of individuals in this way (Wenar 2013b: 217-218). Having outlined Wenar's theory of rights and its advantages over the Will and Interest Theories, I will next turn to Cruft's worry concerning the Kind-Desire Theory's prospects of accommodating our intuitions about respect and outline a reply to this worry.

\section{Rights and respect}

Much theorizing about rights seems to proceed on the implicit assumption that a theory which correctly predicts rights-attributions will also explain how rights are justified. And, indeed, it seems natural to suppose that, in order to determine when a right is attributed, one has to determine 'what rights do for us', i.e., how they strengthen the position of their holders. The Kind-Desire Theory, however, abandons this methodology. It specifies the conditions under which we attribute rights, but it does not provide a unified rationale of the morally relevant relation between rights and right-holders. In Wenar's words, "the analysis carries no commitments regarding the justification of rights" (2013b: 209).

Cruft acknowledges that Wenar's detachment of the justification of rights from their attribution accounts for his theory's success at capturing the ordinary understanding of rights (2013: 209). Yet, he argues that-precisely in virtue of this methodological move - the Kind-Desire Theory also creates a puzzle about the link between rights and respect. Specifically, Cruft suggests that it is intuitively plausible to hold that "[v]iolation of any duty owed to a person, animal or group is disrespectful to that person, animal or group" (2013: 202, italics deleted). ${ }^{7}$ Moreover, he notes that even if the duty in question is not moral but socially created (like the duty not to foul a player in football), insofar as the duty is morally justified and owed to someone, the disrespect shown by violating it is moral in character (Cruft 2013: 203). In addition, to violate a right seems to be disrespectful to the individual who holds the right, rather than to the normative system that warrants the right-attribution (ibid.).

Cruft further suggests that, for the violation of a right to disrespect the rightholder, the right must have "individualistic justification" (2013: 204). And, according to Cruft, a right is individualistically justified if and only if its violation

\footnotetext{
7 Cruft follows Judith Thomson in using the term 'violation' to denote only those rights-infringements, viz. performances (omissions) of actions prohibited (required) by a right, which are unjustified and inexcusable (Cruft 2013: 202-203; Thomson 1990: 122). I will stick to this usage throughout this paper.
} 
"involve[s] failure to respond to something of non-instrumental importance that is genuinely about that being [i.e., the right-holder]" (2013: 214, italics added). Now, Cruft grants that, on the picture that Wenar draws, rights attached to natural kinds and rights attached to roles that come with special duties are individualistically justified (Cruft 2013: 217). After all, Wenar characterizes these rights as enhancing the well-being of their holders or as enabling them to fulfil their obligations, and thus as 'doing something for them'. However, there is a puzzle about the rights that, according to Wenar, are based on role-norms. After all, the attribution of this latter set of rights is supposed to be insensitive to role-bearers' actual psychology, wellbeing, and-it seems - any facts that are genuinely about them. Instead, the KindDesire Theory links these rights to the social significance of the roles occupied by their holders. And, presumably, the social significance of roles is often due to the interests of society as a whole rather than aspects of the individuals who occupy them. Since rights attributed on the basis of role-norms thus do not appear to be individualistically justified, the question is how their violation can be disrespectful to their holders.

For example, take the case of property rights. In Wenar's view, such rights are attributed insofar as there is a norm according to which owners of property have a kind-based desire that certain duties (e.g., to refrain from coercively stripping owners of their property) be fulfilled (Wenar 2013b: 216-217). Further, the KindDesire Theory holds that this kind-based desire is attributed in accordance with the social significance of the role of owner, which in turn is justified (if it is justified) as part of a system of norms that serves the interests of society as a whole. Accordingly, it seems that property rights as characterized by the Kind-Desire Theory are not individualistically justified. But how is it to be explained, then, that violations of property rights are disrespectful? Surely, property rights sometimes serve the interests of their holders. Yet, it seems that even in those cases in which they do not, it is disrespectful to violate them.

I share Cruft's intuitions about the link between rights and respect. Further, I agree that the Kind-Desire Theory may initially appear to create a puzzle about this link. In what follows, however, I introduce a contractualist account of respect which reconciles the Kind-Desire Theory with the intuitive link between rights and respect. In fact, this account of respect shows that, in an important sense, rights as characterized by the Kind-Desire theory can be considered as individualistically justified.

\subsection{An alternative account of respect}

Contractualism is the view that 'what we owe to each other' as a matter of mutual respect for each other's personhood is determined by the principles which no one can reasonably reject (Darwall 2006: chapter 12; Kumar 2003a; Scanlon 1998: 106). In this view, our conduct is disrespectful to a person if and only if that person can reasonably complain about the principle underlying our actions, i.e., if she can demand that we refrain from acting in this way. In favor of this view, Stephen Darwall draws a distinction between two attitudes that one might have towards a person: respect and care (2006: esp. chapter 6). And he ties this distinction to a 
distinction between two kinds of practical reason. He illustrates this point by an example (2006: 5-10).

Suppose one person, A, is standing on the foot of another person, B. According to Darwall, A might recognize two kinds of reasons to remove her foot. On the one hand, A might recognize that by standing on B's foot she is causing B to be in pain. And A might further recognize that pain detracts from the value of a state of the world and that, therefore, she can bring about a more valuable state of the world by removing her foot. If $\mathrm{A}$ removes her foot for this reason, she acts from care or sympathetic concern for B. Darwall observes that this reason is "agent-neutral" since it serves as a reason to remove A's foot from on top of B's, not only for A, but for anyone (2006: 6). Moreover, this reason is "state-of-the-world-regarding" in the sense that its normativity derives from the independent value of some state of the world (ibid.). Accordingly, if the state of the world in question (or an even more valuable one) was to be brought about by another course of action, e.g., by leaving A's foot on B's foot, then this reason would not direct us to remove A's foot at all.

On the other hand, A might acknowledge that B can legitimately demand that $\mathrm{A}$ remove her foot, thus holding A accountable. This reason is agent-relative, in the sense that it serves as a reason to remove A's foot only for $A .{ }^{8}$ Moreover, it is "authority-regarding" as its validity rests, not on the independent value of a state of the world, but on the relation of authority and accountability that holds between B and A. Accordingly, as opposed to the state-of-the-world-regarding alternative, this reason will never serve as a reason to leave A's foot on B's. Darwall labels authority-regarding reasons "second-personal" since they are valid if and only if they are addressable person-to-person within what he calls "the second-person stance" (2006: 8-9). According to Darwall, A respects B only if she acts on this second-personal reason because only this reason reflects B's dignity, understood as the "second-personal authority" to make legitimate demands (2006: esp. chapters 6 and 10$){ }^{9}$

Darwall argues that it follows from this that respect must always be reciprocal (2006: esp. chapter 10). After all, if A's respect for B requires A's recognition of B's authority over A, then it also requires that A recognize that she can be held accountable by B. And, if B is to hold A accountable intelligibly, it must be assumed that $\mathrm{A}$ is capable, not only of acting as B directs, but also of freely endorsing the validity of B's demands, and of directing her will accordingly. Otherwise, any attempt by $\mathrm{B}$ to hold $\mathrm{A}$ accountable will amount to mere coercion. It follows that if $\mathrm{B}$ is to have authority over A, A must be capable of holding herself accountable for acting as B's demands direct. In Darwall's words, A must possess "second-personal competence" (Darwall 2006: 249). But this places limits on what B may demand of

\footnotetext{
8 Admittedly, another person, C, might have $a$ reason to interfere with A's behavior. However, this is not the same reason that A has to remove her foot. To see this, consider that if C successfully interfered, B's demand on A would not wither away-A would still have to answer to B. Conversely, if $\mathrm{C}$ did not interfere but A removed her foot of her own accord, then $\mathrm{C}$ would still be accountable to $\mathrm{A}$ for her refusal to interfere.

9 Note that, in this essay, we are concerned with what Darwall calls "recognition respect", as opposed to "appraisal respect" (1977).
} 
A: B's demands must be such that A can freely impose them on herself, i.e., they must be justifiable to A. But this means that B must assume that A has secondpersonal authority to hold B accountable. Therefore, respect is always reciprocal and linked to the notion of the equal dignity of all members of the moral community. I take it that this element of reciprocity accounts for the 'reasonability' clause in the formulation of contractualism stated above: whether our conduct expresses mutual respect for each other's dignity as persons depends, not just on whether we have reasons to reject the principles underlying each other's actions, but also on whether we can justify these reasons to one another.

The immediately relevant upshot of all this is the following: on the contractualist account of respect, whether disrespect necessarily "involve[s] failure to respond to something of non-instrumental importance that is genuinely about that being", as Cruft suggests (2013: 214), depends on what is meant by "something of noninstrumental importance". Insofar as this clause denotes features of the disrespected being which are intrinsically valuable in the sense that they make a positive contribution to the value of the state of the world in which they are instantiated, contractualists like Darwall will deny that disrespect must always involve a failure to respond to these features. After all, on the contractualist account, respect is a matter of responding correctly to someone's authority, not their value. In Darwall's words, "whereas respecting someone entails relating to her as a being with a dignity, caring for someone involves viewing her as a being with a welfare" (2006: 126). ${ }^{10}$

\subsection{Shared reasons in contractualism}

We have seen that the contractualist account of respect draws a distinction between respect for a person and care for a person's welfare or other valuable features. Nevertheless, this distinction does not rule out the possibility that disrespect for a person always coincides with a failure to take her valuable features into account. After all, it is possible that all the legitimate demands that persons are authorized to make on each other's will and conduct appeal to valuable aspects of their well-being or psychology (as many such demands do, undoubtedly). Accordingly, even on the contractualist account, it might be true that violating a right is disrespectful if and only if the right is conducive to one or more of these features.

However, a suggestion by Scanlon will help us to make some headway. He contends that in determining whether or not a given principle can be reasonably rejected, we cannot take all the objections to the principle that various individuals might have into account (1998: 105). I take this to reflect the reciprocal element of contractualism which I mentioned above: in order for B to reasonably reject the principle underlying A's action, B's rejection must in turn be justifiable to A. And,

\footnotetext{
${ }^{10}$ Kumar makes the companion point that, in contractualism, wronging a person is not reducible to harming a person (2003a). Although in harming a person we often wrong her (since harming often involves acting on a principle that the victim can reasonably reject), the wrong cannot be reduced to the harm that we do to the victim. Rather, the wrong consists in our failure to relate to the victim as someone who can demand that we act on principles that no one can reasonably reject.
} 
arguably, it is not justifiable to A that she should take into account all the reasons that $\mathrm{B}$ might have for rejecting the principle underlying A's actions. More specifically, Scanlon suggests that the reasons that may be invoked in order reasonably to reject a principle are "generic reasons", viz., "reasons that we can see that people have in virtue of their situation, characterized in general terms, and such things as their aims and capabilities and the conditions in which they are placed" (1998: 204). It follows that which reasons B can invoke in order to reasonably reject the principle underlying A's action is independent of B's mental states, well-being, or any other aspect of B, considered as an individual person. Rather, there is a set of generic reasons that is public in the sense that every member of the moral community is entitled to appeal to the reasons included in this set simply in virtue of being a certain type of person in a certain type of situation. ${ }^{11}$

Could kind-based desires that are attributed on the basis of role-norms, which Wenar takes to explain the attribution of certain rights, be included in the public set of reasons for complaint? Scanlon does recognize that some individual rights might ultimately be grounded in the value that certain social practices have for the wider society (2003: 107). For instance, he observes that one might argue that journalists have to be attributed certain rights "if 'the press' is to fulfil its function in society" (2003: 158). One might object, however, that kind-based desires do not pass what Kumar calls the "individual reasons restriction" of contractualism (Kumar 2003a: 9, note 6). More specifically, Kumar points out that, in contractualism, if an individual is reasonably to reject a principle, she must point out some way in which she is adversely affected by the principle's general acceptance (ibid., cf. Scanlon 1998: 118-223). Consequently, Kumar explains, "neither appeals to the aggregate value of outcomes, nor to the aggregate force of individual reasons, are valid grounds for wanting to reasonably reject a proposed principle" (ibid.).

This restriction is a vital aspect of contractualism since it prevents the view from collapsing into consequentialism. After all, contractualism was supposed to emphasise relations of mutual respect, not the aggregate good, as the primary concern of interpersonal morality. What is more, it would be detrimental to my argument if kind-based desires based on role-norms did not honor this restriction. After all, I aim to show that violating rights attributed on the basis of such desires is disrespectful to the right-holder. Hence, it would be problematic if such desires could be shown to stand in no morally important relation to the individual rightholder whatsoever.

However, I do not think that kind-based desires that are attributed to individuals for the sake of society's interests violate the individual reasons restriction. In order to see this, it is important to distinguish society's justification for adding a reason to the public set of generic reasons from an individual's justification for reasonably rejecting a principle by appealing to such a reason. Even if society's justification for viewing promisees as having a desire to have their promises fulfilled is that doing so serves the interests of the public, an individual promisee who appeals to this desire in order to demand that a certain promise to her be kept is not thereby citing the

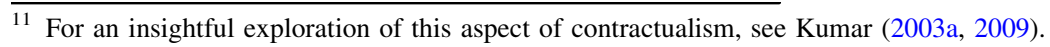


interests of the public as her justification. It seems that, once a reason is part of the public set of generic reasons which a certain type of person is taken to have, not to take this reason into account in our deliberations is to disrespect these personseven if attributing this reason to them in the first place does not serve their interests. After all, to do so is to acknowledge, on the one hand, that persons of their kind have this reason, but to deny, on the other hand, that they have the authority to make demands on our deliberation on the basis of this reason. In other words, it is to relate to them as lacking second-personal authority, and thus dignity.

To illustrate this, let us return to the case of property rights. In Wenar's view, such rights are attributed insofar as there is a norm according to which owners of property have a kind-based desire for the fulfilment of certain duties. Now, on my account, even if the reason why we attribute this kind-based desire to owners is that viewing them in this way is beneficial to society as a whole, we thereby accord to each individual owner a reason to complain about the kinds of actions that count as violations of their property rights. Accordingly, any violation of such a right, even if it consists in the damaging or stealing of a part of the owner's property that she does not even want or need, is disrespectful to the owner. After all, any such violation represents the owner as not having any authority to demand that her property be left to her. Thus, it is to represent her as lacking the authority to make claims on the basis of those reasons on the basis of which second-personally competent owners, qua owners, can make legitimate claims. In other words, to violate a property right is to relate to the owner as a being lacking second-personal standing.

\subsection{Individualistic justification revisited}

I argued that the contractualist account of respect explains how the Kind-Desire Theory is compatible with the intuition that violating rights is disrespectful, even if it does not involve a failure to respond to an independently valuable feature of the right-holder, such as her well-being. But what has become of Cruft's observation that, according to the Kind-Desire Theory, not all rights are individualistically justified? I have not said anything to suggest that this observation is false. So one might take my argument so far to reject the notion that violating rights is disrespectful to the right-holder only if the right in question is individualistically justified. However, I now want to suggest that, given the contractualist account of respect, there is an important sense in which rights as characterized by the KindDesire Theory are individualistically justified.

Cruft seems implicitly to assume that a right is individualistically justified only if it is grounded in a non-relational, valuable aspect of the right-holder. But I think that we can view a right as individualistically justified also if it is based on a relational property of its holder, viz., an aspect of the ways in which she relates to other persons and vice versa. And the aspect of relations between persons that seems particularly fit to play the role of grounding rights within the framework of the Kind-Desire Theory and the contractualist account of respect is equality. There are two reasons for this. First, equality seems to capture the special moral significance of rights, especially their close link with the notion of respect. Second, whether 
treating a person in a certain way counts as relating to her as an equal depends on the kind of society one lives in. Let me expand on each of these reasons in turn.

In his seminal essay on rights, Joel Feinberg draws a connection between rights and the activity of claiming, thus partly anticipating the contractualist account of respect outlined above (1970). In particular, he maintains that whereas normative systems without rights might well be able to protect and promote various valuable aspects of individuals and society, only a regime of rights allows individuals to claim that certain norms be obeyed. For rights are, in Feinberg's words, "especially sturdy objects to "stand upon'" (1970: 252). And he goes on to argue that this fact, i.e., that rights enable us to make claims on each other, accounts for the special moral significance of rights (ibid.). What is this special moral significance? Feinberg suggests that "[h]aving rights enables us to 'stand up like men', to look others in the eye, and to feel in some fundamental way the equal of anyone" (1970: 252, italics added). That is, the moral significance of rights is that they facilitate relations of equality among right-holders.

One might object that any system of norms can treat all persons as equals, e.g., by attaching the same weight to everyone's interests (cf. Hare 1984: 107). However, it seems plausible that only a system that enables persons to make claims on each other will support interpersonal relations (or, more precisely, relatings) of equality. ${ }^{12}$ That is, only if we can address each other person-to-person we will be able to relate to ourselves and each other as equal members of the moral community. And Feinberg goes on to link this way of relating to one another to the notion of respect:

To think of oneself as the holder of rights is not to be unduly but properly proud, to have that minimal self-respect that is necessary to be worthy of the love and esteem of others. [...] To respect a person then, or to think of him as possessed of human dignity, simply is to think of him as a potential maker of claims. (Ibid., italics Feinberg's)

The special significance of rights, on this account, is explained by their claimability. Since rights can be claimed, they allow us to reflect, in our relatings, the equal standing of every member of the moral community. By viewing ourselves as someone who can make claims on others, we regard ourselves as possessing a dignity, and thus as deserving of respect. And by acknowledging the claims that others in turn have on us, we recognize them as morally on a par with ourselves, as equal members of the moral community. In Darwall's words, to recognize someone's legitimate demands on us is "to respect him as a person, or as another person (as someone ‘just like me')” (Darwall 2013a: 29, italics Darwall's). ${ }^{13}$

\footnotetext{
12 For an insightful account of relational equality, see Anderson (1999).

13 Elements of this account of dignity can also be found in Kant's Doctrine of Virtue: "a human being regarded as a person [...] possesses a dignity [...] by which he exacts respect for himself from all other rational beings in the world. He can measure himself with every other being of this kind and value himself on a footing of equality with them" (1996: 6:434-435, italics Kant's). For a similar account, see Waldron (2012).
} 
Thus, relational equality is the right kind of property to figure in an individualistic justification of rights since it seems to capture the special moral significance of rights, especially their link to respect for persons. The second reason why relational equality is particularly apt to play this role within the framework of the Kind-Desire Theory is that whether persons relate to each other as equals seems to be a function, not only of how they treat one another, but also of the kind of society they live in. As Elizabeth Anderson, who advocates relational equality under the heading "democratic equality", explains:

[Democratic equality] requires that everyone have effective access to enough resources to avoid being oppressed by others and to function as an equal in civil society. What counts as 'enough' varies with cultural norms, the natural environment, and individual circumstance. For example, cultural norms and climate influence what kind of clothing one needs to be able to appear in public without shame and with adequate protection from the elements. (1999: 320)

Thus, whether the way an individual is treated by others and the resources to which she has access enable her to stand in relations of equality with others partly depends on the content of certain shared practices of her society and culture. I suggest that the attribution of kind-based desires to the bearers of certain roles is one of these practices. $^{14}$

More specifically, I suggest that if society attributes a certain desire, e.g., that promises be kept, to a certain kind of person, e.g., promisees, this is tantamount to raising the stakes for respecting the equal dignity of persons of this kind. For it seems to make these persons vulnerable to treatments to which they were hitherto not vulnerable. Once it is part of our shared practices to view promisees as having a desire that promises to them be kept, it is disrespectful to break any particular promise without excuse or justification-even if the promisee in question has no independent interest in the content of the promise. Not to acknowledge a particular promisee's kind-based desire in the fulfillment of the promise as a legitimate ground of complaint is to make an exception to the shared practice of viewing promisees in this way. It is thus to deny her the authority to make claims by invoking the shared reasons for complaint which every person of her kind can legitimately invoke. And this, in turn, is tantamount to a failure to acknowledge her equal dignity as a member of the community.

\section{Objections}

In the previous section, I argued that Wenar's Kind-Desire Theory of rights can be reconciled with the link between rights and respect highlighted by Cruft. In this section, I will discuss some potential objections. I hope that this will further clarify the view I am proposing.

\footnotetext{
14 Put another way, kind-based desires form part of what Rawls calls "the social bases of self-respect" (1980: 526).
} 


\subsection{Who has the strongest complaint?}

One might object that it is not particularly helpful to employ contractualism in order to save a theory of rights. After all, as Wenar himself argues, contractualism is strikingly unsatisfactory with regard to its treatment of rights (2013a). He observes that, on their most plausible reading, "[c]ontractualist principles ascribe rights to the strongest complainants" (2013a: 392). That is, a person is attributed a right if her reasons to complain about alternative arrangements, i.e., arrangements under which she does not have the right in question, are stronger than anyone else's reasons to complain about the right-attribution. Wenar argues that this proposal is unsatisfactory for two reasons.

The first problem is that there are many cases in which the right-holder does not seem to be the person whose complaint fixes the principle which attributes the right (Wenar 2013a: 392-395). For example, as we've seen in Sect. 2, promisees are attributed a right to have their promises fulfilled, but this right is not attributed on the basis of a reason that promisees (qua individual persons) have to want their promises to be fulfilled. I think that this objection highlights a genuine gap in the most common versions of contractualism, such as Scanlon's formulation of the view (1998). If reasons for complaint explain the moral significance rights, why are there rights that do not seem to reflect the legitimate complaints of their holders, but the interests of some third party or collective? However, here it is of vital importance to note that I am not advertising contractualism as a complete theory of rights. I am neither suggesting that contractualism coincides with the Kind-Desire Theory, nor that it should replace the latter. Instead, I propose that the Kind-Desire Theory of rights and contractualism can form a mutually beneficial synthesis. Now, one of the lessons that the Kind-Desire Theory teaches us is that society sometimes attributes reasons for complaint to individuals, not based on their actual psychology, wellbeing or other non-relational features, but on the basis of the interests of society. My suggestion is therefore that in cases in which there does not seem to be much at stake for the right-holder, considered as an individual, she is nonetheless the strongest complainant because she is attributed a kind-based desire that does not correspond to her actual psychology or well-being. Thus, Wenar's very own theory solves the problem that he identified for contractualism by pointing out the possibility that a reason for complaint can be founded on a kind-based desire rather than in the psychological states or well-being of an individual. ${ }^{15}$

\subsection{Not all contractualist principles ascribe rights}

The second problem for contractualism that Wenar points out is that contractualism takes all moral principles to be fixed by the strongest complaint, but only some

\footnotetext{
15 Wenar seems to anticipate that his own theory will provide the answer to this challenge for contractualism. He writes: "[u]ntil I or someone else presents an adequate account of directed moral requirements, locating rights within contractualism will remain a standing challenge" (2013a: 397).
} 
moral principles ascribe rights (2013a: 392). ${ }^{16}$ Indeed, it seems that any plausible moral theory will advocate requirements which are not correlated with rights, e.g., a principle of beneficence.

However, I think that this problem can again be solved with the resources provided by the Kind-Desire Theory. According to this theory, for a requirement to be correlated with a right it is not only necessary that there is an individual that has a kind-based desire in the fulfillment of the requirement but also that the requirement's formulation, if made explicit, mentions the right-holder (condition 1), and that it would be appropriate to enforce the requirement (condition 3) (Wenar 2013b: 219). I suggest that contractualists can explain moral principles which do not attribute rights by pointing out that one or both of these conditions is not met.

In the case of a principle of beneficence, condition 3 seems to be unfulfilled. Principles of beneficence are notoriously indeterminate in that they do not prescribe specific external acts (see Hope 2014). Rather, in any given situation it takes judgement to determine which beneficent action (if any) is required by the principle. For example, one might argue that I am required to help you carry your washing machine to your flat upstairs if I have no reason not to do so whatsoever (i.e., I do not have anything better to do, I am not suffering from any bodily impairments, etc.). But I am certainly not required to help you if a close friend of mine has just been in a horrible car accident and I am on my way to the hospital to see if he is alright. Because of this indeterminacy it is not possible - and, a fortiori, not appropriate - to enforce the requirement issued by a principle of beneficence. And this plausibly explains why this principle does not attribute any rights. ${ }^{17}$ Once again, Wenar's theory solves a problem of contractualism, proving the fruitfulness of combining the two views.

\subsection{Some directed duties are not demandable}

Cruft makes two objections to the view that to violate a directed duty is disrespectful because compliance with the duty can legitimately be demanded (2013: 215). His first objection is that compliance with some directed duties cannot be appropriately demanded. For example, according to Cruft, it would be morally impermissible to demand that people fulfill their duty of gratitude. In fact, it seems that demanding compliance with this duty would undermine the possibility of showing genuine gratitude. Yet, it seems that I fail to respect you if I do not thank you, say, for helping me to carry a heavy object.

First of all, I do not share Cruft's intuition that it is morally impermissible to demand gratitude. It is certainly not very tactful to do so in many circumstances, but I do not see any reason to think that it would be morally wrong. Second, while it is true that it is sometimes self-undermining to demand what one is owed, the account

\footnotetext{
${ }^{16}$ Scanlon never specifies which principles he takes to ascribe rights, and he denies that this question is of great importance (2013: 405).

${ }^{17}$ One interesting question is whether the duty of beneficence is nevertheless directed such that whenever we are required to perform a certain act of beneficence, we owe this performance to the patient of our beneficence. I am inclined to affirm this (also see note 1), although the answer that is traditionally given in the literature is no.
} 
presented here does not claim that one can effectively demand compliance with all the duties owed to one. It suffices that one has reasons that would morally warrant such a demand. Here, it is helpful to note that, on Darwall's account, certain legitimate demands are "in force' from the moral point of view" (2006: 9, 2006: 244, note 2, 2007: 65, 2013a: 23, 2014: 10-11). That is, in our deliberations we must view persons as though they explicitly invoked their authority to make these demands, independently of whether they formulate them explicitly.

\subsection{Demandability does not single out the right-holder}

Next, Cruft argues that it seems intuitively plausible that everyone can legitimately demand compliance with anyone's rights; hence, the standing to demand can hardly serve to single out the right-holder as the victim of disrespect (Cruft 2013: 215; cf. May 2015: 527).

However, I think that the account on which disrespect is a matter of neglecting legitimate demands has the resources to single out the right-holder as the party that is disrespected by a rights-violation. For while every member of the moral community can legitimately demand that a right not be violated, the right-holder seems to have a special, privileged standing to hold perpetrators accountable. Darwall captures this differential standing by distinguishing between the "representative authority" of members of the moral community and the "individual authority" of the right-holder (Darwall 2013a: 32-39). ${ }^{18}$ Moreover, he points out that this difference in authority is reflected by the kinds of reactive attitudes each of the parties may adopt: while all members of the moral community may adopt impersonal reactive attitudes (such as blame or indignation), the right-holder may adopt personal reactive attitudes (such as resentment) towards the perpetrator (ibid.).

\subsection{Unwaivable rights}

Since the account presented here emphasizes the right-holder's authority to demand compliance with her rights, one might object that, similarly to the Will Theory, it cannot accommodate the disrespectfulness of violating unwaivable or inalienable rights (Wenar 2013b: 203, note 1).

However, the contractualist account does not imply that the disrespectfulness of a rights-violation depends on whether or not the right-holder chooses to demand compliance. For the authority which underwrites a right's moral significance need not be discretional authority (cf. May 2015: 527). Indeed, on the account presented here, at least some of the legitimate demands attributed to persons must be viewed as 'in force' irrespective of whether they choose to invoke them. As noted in

\footnotetext{
18 Simon May notes that, if this argument of Darwall's is to address Cruft's objection, it must explain the distinction between the authority of the right-holder and that of the rest of the moral community without relying on the fact that the right-holder, as opposed to the rest of the moral community, is disrespected by rights-violations (2015: 527-528). Hence, I think that the moral community's representative authority should be construed as derived from (and thus as dependent on) the right-holder's individual authority (pace Darwall 2007: 60-64).
} 
Sect. 3, the practice of addressing demands necessarily presupposes the equal dignity of all members of the moral community. This presupposition is plausibly seen as limiting which demands can legitimately be addressed or waived (cf. Darwall 2006: 263-268). ${ }^{19}$

\subsection{Disrespect to the person qua individual?}

One might object that, strictly speaking, my argument in this paper only characterizes rights-violations as disrespectful to the right-holder qua member of a certain kind but not to the individual who holds the right. ${ }^{20}$ The idea underlying this objection is that one can step back from one's identity as a kind-member and thus shield oneself from the disrespect others show to this identity.

However, as I argued above, respect for a person's dignity requires taking into account her legitimate complaints, including those attributed to her in virtue of her roles. Accordingly, on my view, a person's dignity is partly socially constituted in the sense that what actions constitute instances of disrespect to her dignity partly depends on which kind-based desires her community attributes to her. Therefore, one cannot step back from one's roles and divorce disrespect to these roles from disrespect to one's dignity. My view can thus be characterized as depicting person as a (meta-) kind which comes with the kind-based desire to have one's more specific kind-based desires fulfilled. ${ }^{21}$ Indeed, insofar as we are committed to respecting our own dignity as a necessary presupposition of the second-person stance, my account suggest that, to a certain degree, we are required to take our roles seriously and insist on our rights as a matter of self-respect. ${ }^{22}$

\subsection{Rights of the incompetent}

The final objection states that the contractualist account presented here cannot accommodate the rights of non-human animals ${ }^{23}$ and other creatures who are incapable of making demands. ${ }^{24}$ There are at least two potential lines of response to this objection.

\footnotetext{
19 Indeed, Darwall suggests that this presupposition gives rise to certain requirements of self-respect, e.g., the requirement against servility suggested by Thomas Hill (Darwall 2013b: 121; Hill 1973).

${ }^{20}$ I am indebted to Antony Duff for suggesting this objection.

21 For suggesting this way of stating my view, I am once again indebted to Antony Duff.

22 I should again emphasize that I am assuming that the normative system of which the roles in question form part is morally justified. Moreover, it is important to note that my view does not prohibit abandoning a role that one does not appreciate. It merely states that as long as one occupies the role, one should take the rights that are attached to it seriously as a matter of self-respect.

23 It would be premature to rule out that some non-human animals are second-personally competent (cf. Darwall 2006: 43, note 8, 175). Frans DeWaal's research suggests that some non-human animals might possess rudimentary second-personal capacities or, at least, that the difference between humans and nonhumans in this respect is one of degree rather than kind (DeWaal 1996).

24 For a criticism of contract theories along these lines, see Nussbaum (2007). Note that this objection does not affect contractualism quite as strongly as the Will Theory. Some beings (e.g., children and the comatose) possess the capacity to make demands but not the ability to exercise normative control.
} 
First, note that the Kind-Desire Theory explains why rights-attributions to second-personally incompetent beings make sense to ordinary speakers (because these beings can be attributed kind-based desires qua members of natural kinds). What the account presented here seems to deny is that violating these rights is disrespectful. The first potential line of response would just be to say that this is precisely as it should be. However, I suspect that this might be unsatisfactory to many readers.

The second line of response would be to suggest that there is a shared practice of attributing legitimate demands to beings incapable of second-personal address. These demands would not be too different from those that we attribute to secondpersonally competent beings by virtue of their kind-membership, and thus independently of their psychological states and well-being. Just like these more familiar demands, demands attributed to second-personally incompetent beings would be 'in force' for the purposes of moral reasoning, regardless of whether or not they are actually formulated by these beings. One difficulty for this view is that second-personally incompetent beings lack the very capacity to make demands. Perhaps one could argue that the moral community has established the practice of attributing, not only demands, but also the capacity to address demands to these beings. But another objection to this proposal might be that, although it might explain why we fail by a standard that we set when we mistreat second-personally incompetent beings, it does not explain why we thereby disrespect them. ${ }^{25}$ Yet, I think that this proposal is worth further exploration.

\section{Conclusion}

In this essay, I argued that a contractualist account of respect can reconcile the Kind-Desire Theory with the intuition that violating a right disrespects the rightholder. The main argument consisted of three steps. The first step was to contend that respecting a person is not conceptually tied to correctly responding to her (nonrelational) valuable features. Instead, respect requires taking into account a person's reasons for legitimate complaint. The second step was to show that a person's reasons for legitimate complaint flow from a public set of shared reasons that need not coincide with the reasons for complaint that she has qua the particular individual she is. Third, I argued that this public set of reasons might contain kind-based desires flowing from role-norms. In light of this argument, I suggested (pace Cruft) that rights attributed on the basis of role-norms can be viewed as individualistically justified since they allow their holders to stand in relations of equality with others. Furthermore, I tried to show that the view presented in this essay can be defended against a series of potential objections. I conclude that the contractualist account of respect and the Kind-Desire Theory of rights form a fruitful synthesis.

\footnotetext{
25 For structurally similar objections to other non-consequentialist approaches to animal ethics, see Sachs (2015: 643, 646-647).
} 
Acknowledgements For helpful comments and feedback on earlier drafts of this paper, I am grateful to Rowan Cruft, Ben Sachs, Jens Timmermann, and Antony Duff. I would also like to thank the organizers and participants of the 2015 Annual Meeting of the Scots Philosophical Association for giving me the opportunity to present this work. Finally, I would like to thank my anonymous reviewers at Philosophical Studies. This work was developed with the financial support of the German Academic Exchange Service and the St Andrews/Stirling Philosophy Graduate Programme.

Open Access This article is distributed under the terms of the Creative Commons Attribution 4.0 International License (http://creativecommons.org/licenses/by/4.0/), which permits unrestricted use, distribution, and reproduction in any medium, provided you give appropriate credit to the original author(s) and the source, provide a link to the Creative Commons license, and indicate if changes were made.

\section{References}

Anderson, E. S. (1999). What is the point of equality? Ethics, 109(2), 287-337.

Cruft, R. (2013). Why is it disrespectful to violate rights? Proceedings of the Aristotelian Society, 113(2), 201-224.

Darwall, S. (1977). Two kinds of respect. Ethics, 88(1), 36-49.

Darwall, S. (2006). The second-person standpoint: Morality, respect, and accountability. Cambridge, MA: Harvard University Press.

Darwall, S. (2007). Reply to Korsgaard, Wallace, and Watson. Ethics, Symposium on Stephen Darwall's The Second Person Standpoint 118(1), 52-69.

Darwall, S. (2013a). Bipolar obligations, repr. In his Morality, authority, and law: Essays in secondpersonal ethics I. Oxford: Oxford University Press.

Darwall, S. (2013b). The value of autonomy and autonomy of the will, repr. In his Morality, authority, and law: Essays in second-personal ethics I. Oxford: Oxford University Press.

Darwall, S. (2014). Why Fichte's second-personal foundations can provide a more adequate account of the relation of right than Kant's. Grazer Philosophische Studien, 90, 5-20.

DeWaal, F. B. M. (1996). Good natured: The origins of right and wrong in humans and other animals. Cambridge, MA: Harvard University Press.

Feinberg, J. (1970). The nature and value of rights. The Journal of Value Inquiry, 4(4), 243-257.

Hare, R. (1984). Rights, utility, and universalization: Reply to J. L. Mackie. In R. G. Frey (Ed.), Utility and rights. Minneapolis: University of Minnesota Press.

Hart, H. L. A. (1982). Legal rights. In his Essays on Bentham: Jurisprudence and political philosophy. Oxford: Clarendon Press.

Hart, H. L. A. (1955). Are there any natural rights? The Philosophical Review, 64(2), 175-191.

Hill, T. E. Jr. (1973). Servility and Self-Respect. The Monist, 57(1), 87-104.

Hohfeld, W. N. (1964). Fundamental legal conceptions as applied in judicial reasoning. In W. W. Cook (Ed.). New Haven: Yale University Press.

Hope, S. (2014). Kantian imperfect duties and modern debates over human rights. Journal of Political Philosophy, 22(4), 396-415.

Kant, I. (1996). The metaphysics of morals. In M. J. Gregor (Ed. and trans.), The Cambridge edition of the works of Immanuel Kant: Practical philosophy. Cambridge: Cambridge University Press. Page references are to page numbers of the Preußische Akademie Edition.

Kramer, M. H., \& Steiner, H. (2007). Theories of rights: Is there a third way? Oxford Journal of Legal Studies, 27(2), 281-310.

Kumar, R. (2003a). Reasonable reasons in contractualist moral argument. Ethics, 114(1), 6-37.

Kumar, R. (2003b). Who can be wronged? Philosophy \& Public Affairs, 31(2), 99-118.

Kumar, R. (2009). Wronging future people: A contractualist proposal. In A. Gossaries \& L. Meyer (Eds.), Intergenerational justice. Oxford: Oxford University Press.

MacCormick, N. (1977). Rights in legislation. In P. M. S. Hacker \& J. Raz (Eds.), Law, morality, and society. Oxford: Clarendon Press. 
MacCormick, N. (1984). Children's rights: A test case for theories of rights, repr. In his Legal right and social democracy. Oxford: Clarendon Press.

May, S. C. (2015). Directed duties. Philosophy Compass, 10(8), 523-532.

Nussbaum, M. (2007). Frontiers of justice: Disability, nationality, species membership. Cambridge, MA: Belknap Press.

Rawls, J. (1980). Kantian constructivism in moral theory. The Journal of Philosophy, 77(9), 515-572.

Raz, J. (1984). On the nature of rights. Mind, 93, 194-214.

Sachs, B. (2015). Non-consequentialist theories of animal ethics. Analysis, 75(4), 638-654.

Scanlon, T. M. (1998). What we owe to each other. Cambridge, MA: Belknap Press.

Scanlon, T. M. (2003). The difficulty of tolerance. Cambridge: Cambridge University Press.

Scanlon, T. M. (2013). Reply to Leif Wenar. Journal of Moral Philosophy, 10, 400-405.

Steiner, H. (1994). An essay on rights. Oxford: Blackwell Pub.

Streenivasan, G. (2005). A hybrid theory of claim-rights. Oxford Journal of Legal Studies, 25(2), 257-274.

Streenivasan, G. (2010). Duties and their direction. Ethics, 120(3), 465-494.

Thomson, J. J. (1990). The realm of rights. Cambridge, MA: Harvard University Press.

Waldron, J. (2012). Dignity, rank, and rights. Oxford: Oxford University Press.

Wenar, L. (2005). The nature of rights. Philosophy \& Public Affairs, 33(3), 223-252.

Wenar, L. (2008). The analysis of rights. In B. Colburn, C. Grant, A. Hatzistavrou, \& M. Kramer (Eds.), The legacy of H. L. A. Hart: Legal, political, and moral philosophy. Oxford: Oxford University Press.

Wenar, L. (2013a). Rights and what we owe to each other. Journal of Moral Philosophy, 10, 375-399.

Wenar, L. (2013b). The nature of claim-rights. Ethics, 123(2), 202-229.

Wenar, L. (2015). Rights. In E. N. Zalta (ed.), The Stanford Encyclopaedia of Philosophy. http://plato. stanford.edu/archives/fall2015/entries/rights/. 